\title{
CASE STUDY ON SUBCONTRACTING ARRANGEMENTS IN THE SCAFFOLDING SUPPLY CHAIN OF A LIQUEFIED NATURAL GAS INFRASTRUCTURE PROJECT
}

\author{
Robert LOPEZ ${ }^{\mathrm{a}}$, Heap-Yih $\mathrm{CHONG}^{\mathrm{a}}$, Sungkon MOON${ }^{\mathrm{b}}$, Xiangyu WANG ${ }^{\mathrm{c}, \mathrm{d}}$ \\ ${ }^{a}$ School of Built Environment (SoBE), Faculty of Humanities, Curtin University, \\ GPO Box U1987, 6845, Perth, Australia \\ ${ }^{b}$ School of Engineering, Faculty of Science, Engineering and Technology - Centre for Sustainable Infrastructure, \\ Swinburne University of Technology, Level 8, ATC, John Street, 3122, Melbourne, Australia \\ ${ }^{c}$ Australasian Joint Research Centre for Building Information Modelling, \\ Faculty of Humanities, Curtin University, GPO Box U1987, 6845, Perth, Australia \\ ${ }^{d}$ Department of Housing and Interior Design, College of Human Ecology, Kyung Hee University, \\ 26 Kyungheedae-ro, 130-701, Seoul, Republic of Korea
}

Received 18 Apr 2017; accepted 25 Sep 2017

\begin{abstract}
The objective of the study presented in this paper is to determine the characteristics of the scaffolding supply chain in a liquefied natural gas (LNG) infrastructure project. This research is significant as the outsourcing of scaffolding is integral to its use and productivity toward LNG infrastructure project completion. As such, this paper presents the research undertaken on the subcontracting of scaffold manufacturing, supplying and delivering. It focuses upon the organisations, management and control in scaffolding subcontracting. A comparative analysis of three organisations was carried out to reveal issues with current practice in manufacturing, supplying and delivering scaffold products for assembly onsite. Their management and control approaches are also compared and contrasted. It is found that, while the divided contract approach may help save costs, enhance market exposure and is ideal when choice of subcontractor is limited, its risks can impact upon the entire project and be difficult for the contractor to control. The limited background in scaffolding studies and importance of subcontracting within LNG infrastructure projects has made this research timely. This paper identifies issues in relation to quality assurance, warranties and rework, which have the potential to mitigate any cost benefits obtained from subcontracting practices within this supply chain.
\end{abstract}

Keywords: liquefied natural gas, infrastructure, outsourcing, scaffolding, subcontracting, supply chain.

\section{Introduction}

Scaffolding systems would enable for different levels of temporary support structures. They allow workers to work and access their job tasks in convenient ways that would otherwise not be possible without them. The effective organisation and contracting of the supply of these temporary structures would be significant in their contribution toward both the liquefied natural gas (LNG) infrastructure project timeline and budget. Previous studies of scaffolding have traditionally focused upon improving their safety through the use of bamboo truss-out scaffolds (Chan et al. 2008), analysis of components (Rubio-Romero et al. 2012), identification of the load-bearing capacity of nodes (Pieńko, Błazik-Borowa 2013), measurement of safety performance (Choudhry 2014) and development of a BIM-based safety platform (Kim et al. 2016).

Some related scaffolding studies have also investigated the design of movable scaffold systems (Pan 2009;
Póvoas 2012), use of bamboo materials (Chung, Yu 2002; $\mathrm{Yu}$ et al. 2005), as well as educational aspects for decision making and supervision (Goh, Binte-Sa'adon 2015). Research that concentrated solely on the management aspects of scaffolding would be very difficult to find at present. In particular, very limited studies have considered scaffolding in LNG infrastructure projects, except for recent research on productivity (Moon et al. 2016), and a scheduling algorithm (Hou et al. 2017), which are part of an ongoing Australian Research Council (ARC) funded research project.

This research is a subsequent part of this funded project and aims to determine the characteristics of the scaffolding supply chain in a LNG infrastructure project. Case study approach was adopted for the in- depth analysis of the scaffolding practice. The paper provides solutions and insightful references to the problem of sub-

Corresponding author: Robert Lopez

E-mail: r.lopez@curtin.edu.au 
contracting procurement method selection in this supply chain. This research is significant as the subcontracting of scaffolding would be integral to its subsequent use, as well as productivity, toward LNG infrastructure project completion.

\section{Literature review}

\subsection{Organisational outsourcing and insertion}

Scaffolding works describe as common outsourcing jobs that are erected by subcontractors. However, the outsourcing practice has always affected the planning and management of construction projects (Kim et al. 2016). The organisational decision to outsource would be fundamentally influenced by searching for business partners, investments based upon working relationships and incomplete contracts (Grossman, Helpman 2005; Spencer 2005). Despite these, we would already know that there are measurable benefits of outsourcing to organisations. For example, Bhagwati et al. (2004), in their study of the "muddles" over outsourcing, had argued that the electronic mediums of phone and internet have together removed the burdens of information sharing between buyers and sellers. This would be particularly true for working relationships between geographically dispersed organisations (Bhagwati et al. 2004). Girma and Görg (2004), in their study of outsourcing, foreign ownership and productivity in the UK, had found that outsource intense organisations would positively facilitate their overall rate of production. This would normally be due to more of their work being done in less time (Girma, Görg 2004).

In addition Leahy and Montagna (2009), in their comparison between outsourcing and foreign direct investment (FDI), had found that organisations with higher costs of production generally have a greater tendency to outsource. This would be because the same work could also be done at a lower cost, usually by another organisation overseas that has inserted themselves into the local market (Humphrey, Schmitz 2002). Humphrey and Schmitz (2002), in studying the impacts of insertion upon upgrading, had argued that organisations could insert themselves into global markets in unique ways. These ways may include marketing, advertising, tendering, reputation and word of mouth (Humphrey, Schmitz 2002). You-Wei and Jin (2005) had found that gradual insertions of Chinese organisations into global markets over time noticeably improved FDI and international trade. They had also advocated a need for some organisations to improve upon their marketing strategies (You-Wei, Jin 2005).

\subsection{Project governance and cooperation}

The LNG infrastructure project client would have some degree of control over the organisations in the scaffolding supply chain. Such control would be achievable through some form of alliance arrangement between the organisations without the need to subcontract necessarily. For instance, the LNG infrastructure project client's control over the functions of subcontractors would be limited and often divorced from their real time issues of resourcing, quality and productivity (Webster et al. 1997). The continual need for organisations within supply chains to continually improve their cooperation and innovate would call for them embracing effective information technologies (IT), just in time (JIT) deliverables, as well as total quality management (TQM) (Jones, Kraatz 1997). Indeed, the late twentieth century has witnessed the beginnings of an ever increasing dependence of activities upon computerised IT (Webster et al. 1997).

\subsection{Project coordination, communication and infor- mation flow}

The conditions of the contracting and subcontracting arrangements implemented significantly influences the degree of coordination, communication and flow of information between organisations in a supply chain (Titus, Bröchner 2005). Jha and Iyer (2006) had found the main factors that determine coordination in Indian projects to concern planning for quality, remediating defects, optimising resources, project stakeholder inputs, contract documents, as well as continuous improvement. Depending upon these conditions, the contractor may even be obliged to propose their list of subcontractors for the client to approve before commencing the LNG infrastructure project (Jones, Kraatz 1997). Likewise, a representative of the head contractor had emphasised this approach in his reflection of the LNG infrastructure project:

\section{"Lessons were learnt between all the parties ... Use the same contractors in future who are aware of historical issues" (head contractor representative).}

Typically, there are metaphorical boundaries that physically separate subcontracted organisations in the supply chain which would serve to reduce the real time interactivity between the offsite manufacturing of scaffolding products and the contractor's work after their delivery onsite. The following scaffolding products in use for an LNG infrastructure project would typically be the same as those used within other project types (Atlantic Pacific Equipment Inc. 2017):

- Ring locks - these normally include spigots, braces, brackets, transoms, castors, collars, ledgers and jacks;

- Tubes - these are either aluminium, steel or a combination of both, which normally include joiners and fittings; as well as

- Working platforms - these normally include clamps, planks and toe boards.

The contractor still needs to communicate requirements and issues with their subcontracted scaffolding supplier, which would in turn affect the delivery to the site. A dynamic information exchange between them should exist so that the LNG infrastructure project client's require- 
ments could, at least in part, influence the manufacturing of scaffolding products to be supplied. This is because the separation of organisations in the scaffolding supply chain would not make such dynamic communication easy (Standen 1995; Webster et al. 1997). This would more importantly require a LNG infrastructure project culture based upon mutual support and trust. Achieving both of these would be much easier said than done. Especially after the risks associated with subcontracting are factored into consideration (Hartmann, Caerteling 2010).

\subsection{Subcontracting risks}

To distinguish between the characteristics of LNG infrastructure subcontracting, as well as the context of scaffold supply in particular, would require the consideration of selecting organisations within the supply chain, control of manufacturing the products and scheduling the work (Webster et al. 1997; Government of Western Australia 2012). This would be because Enshassi et al. (2012), in their survey on the causes of subcontracting issues, had found the main risks to be the potential for subcontractor replacement during work, financial problems when progress payments were delayed, non-conformances or contraventions, as well as inadequacies in the quality of their workmanship. Knowing the contractor's vulnerabilities, a subcontractor may renege on their agreement. Likewise, the supplier's opportunism could also be a risk to the contractor if sole sourcing is a subcontracting policy of theirs (Artto et al. 2008; Enshassi et al. 2012).

\subsubsection{Subcontractor selection}

Subcontractor selection is an issue of concern for contractors, particularly in the supply of scaffolding, and can be performed at two or more levels. At level one, a list of external organisations that could supply the necessary manufactured scaffolding products when subcontracted are generated and evaluated, sometimes through a formal corporate appraising procedure. Agreements to arrange work for the listed organisations could also be made informally. At levels two and beyond, the subcontracted supplier would then in turn need to subcontract the delivery of the necessary scaffolding products that complies with the contractor's program. This process could be based on straightforward working relationships of trust (Artto et al. 2008; Hartmann, Caerteling 2010).

Manu et al. (2015) had found the main factors influencing trust to concern change management, payment, economic situation, future work, performance and circumstance. Additionally, Liu et al. (2015) purport that culture influences beliefs, thoughts, practices and behaviours. Each of these would serve to increase the LNG infrastructure project risks, particularly when they differ from those of the host country and inform the risk management of each stakeholder organisation (Liu et al. 2015). These factors may also make the subcontracting process a complex mechanism of business transactions (Artto et al. 2008).

\subsubsection{Project scheduling}

Any models that simulate long term or permanent subcontracting relationships would be of minimal relevance to the case studies presented in this paper as LNG infrastructure projects by their nature are bespoke and have temporary durations (Webster et al. 1997; Government of Western Australia 2012). Despite previous studies on the project schedule, none of them would explicitly address the scheduling of the scaffolding supply chain in particular. Moreover, the scaffolding supply chain is a dynamic process that normally requires continual communication of information on the requirements of the manufactured products in real time so that orders can be modified and any defects returned for replacement under warranty without delaying the LNG infrastructure project schedule (Standen 1995). Ironically, it is from this real time awareness that would also come an ability to forecast the future work of every organisation in the scaffolding supply chain in order to help them better keep track of their human resourcing and productivity (Hartmann, Caerteling 2010).

\subsection{Subcontracting procurement strategies}

Subcontracting arrangements have been established for various reasons. Subcontracting based on capacity is established to satisfy a sudden demand and can indicate the firefighting tendencies of organisational management. Contrastingly, subcontracting based on specialisation is established to obtain the specialist expertise and technology that would otherwise not be available. The outsourcing of oil and gas technology would often be an initial firefighting reaction. This could occur to fulfil a need and the imbalance may result in incompatibilities with the rest of the group (Webster et al. 1997).

On the other hand, subcontracting based on economics is established when it is cheaper for another organisation to do the work than it would otherwise be in house (Webster et al. 1997). Subcontracting based upon both specialisation and economics can reveal the business sustainability focus of organisational management (Artto et al. 2008). It is primarily based upon capacity, specialisation, as well as economics, which influence organisations to implement traditional, design and build, or divided approaches toward their subcontracting practices. The main characteristics, advantages and disadvantages of each subcontracting procurement method are provided in Table 1 (Standen 1995; Webster et al. 1997; Rowlinson, McDermott 1999; Walker 2007; Walker, Rowlinson 2008; APCC 2014; McGraw Hill Construction 2014).

Whilst the divided contract approach would not be an established type of contract in the construction industry, their procurement methods of project manage and management contracting would be. Both of these procurement methods would fundamentally share the same characteristics, benefits and shortcomings. The divided contract approach has been used to describe the contracting of all the project risks onto either a particular person 
Table 1. Characteristics of subcontracting procurement methods

\begin{tabular}{|c|c|c|c|}
\hline $\begin{array}{l}\text { Subcontracting } \\
\text { Procurement }\end{array}$ & Main Characteristics & Advantages & Disadvantages \\
\hline $\begin{array}{l}\text { Traditional } \\
\text { Approach }\end{array}$ & $\begin{array}{l}\text { - Design; } \\
\text { - Bid; and } \\
\text { - Build. }\end{array}$ & $\begin{array}{l}\text { - Contractor owns design and fabrication; } \\
\text { - Specialists undertake the work; } \\
\text { - All responsibility and risks are trans- } \\
\text { ferred onto the contractor; } \\
\text { - Creates opportunities for practitioners; } \\
\text { - Subcontractors used to maintain pro- } \\
\text { ductivity; } \\
\text { - Increases business flexibility; } \\
\text { - Facilitates greater market competition. }\end{array}$ & $\begin{array}{l}\text { - Commercial contracting; } \\
\text { - Requires understanding of ar- } \\
\text { rangement; } \\
\text { - Requires sound understanding } \\
\text { of tax implications; } \\
\text { - Lump sum payment; } \\
\text { - Selection based upon lowest } \\
\text { price; } \\
\text { - Problematic and adversarial } \\
\text { working relationships. }\end{array}$ \\
\hline $\begin{array}{l}\text { Design and } \\
\text { Build } \\
\text { Approach }\end{array}$ & $\begin{array}{l}\text { - Build, operate and } \\
\text { transfer (BOT); } \\
\text { - Build, own, operate } \\
\text { and transfer (BOOT); } \\
\text { - Build, own and man- } \\
\text { age (BOM); } \\
\text { - Turnkey; or } \\
\text { - Novation. }\end{array}$ & $\begin{array}{l}\text { - Design and fabrication by same entity; } \\
\text { - Simple singular accountability; } \\
\text { - Overlapping of design and fabrication; } \\
\text { - Opportunity to increase efficiency; } \\
\text { - Various financial, leadership and pay- } \\
\text { ment options. }\end{array}$ & $\begin{array}{l}\text { - Requires justifying design / } \\
\text { fabrication methodology; } \\
\text { - Subcontracting based upon } \\
\text { specialisation / economics; } \\
\text { - Promotes firefighting reactions. }\end{array}$ \\
\hline $\begin{array}{l}\text { Divided } \\
\text { Contract } \\
\text { Approach }\end{array}$ & $\begin{array}{l}\text { - Project management; } \\
\text { or } \\
\text { - Management contract- } \\
\text { ing. }\end{array}$ & $\begin{array}{l}\text { - Tailor made to suit certain character- } \\
\text { istics; } \\
\text { - Subcontractor prices included into con- } \\
\text { tract sum; } \\
\text { - Performed by the people involved; } \\
\text { - Incompatibilities can either be em- } \\
\text { braced / neglected / outsourced; } \\
\text { - Specialists can undertake the work; } \\
\text { - Subcontractor responsible for own edu- } \\
\text { cation, practices and efficiencies. }\end{array}$ & $\begin{array}{l}\text { - No established criteria; } \\
\text { - Commercial contracting; } \\
\text { - Requires understanding of ar- } \\
\text { rangement; } \\
\text { - Requires sound understanding } \\
\text { of tax implications; } \\
\text { - Lump sum payment; } \\
\text { - Selection based upon lowest } \\
\text { price; } \\
\text { - Problematic and adversarial } \\
\text { working relationships; } \\
\text { - Ensuring cooperation and con- } \\
\text { structability require effort. }\end{array}$ \\
\hline
\end{tabular}

or entity by the client. This person or entity would represent them in managing the project on their behalf. In doing so, the management person or entity would then typically divide their entire project risks onto the other stakeholders engaged, often in whichever way they see fit. This division of project risks onto the other stakeholders would normally be undertaken through the use of subcontracts (Walker, Rowlinson 2008; CIOB 2010; Hartman, Caerteling 2010; APCC 2014).

\subsection{Theoretical foundation and research gap}

From a macro perspective of scaffolding research, the related previous studies primarily focus upon its safety and design, particularly for different scaffold systems and their materials. With regard to the scaffolding supply chain, recent literature has merely associated the existing outsourcing and subcontracting principles for scaffolding practice in LNG projects. Basically, the generic nature of these management theories for the scaffolding supply chain may not be suitable for the highly complex and often unstructured practices of these projects. Scaffolding research has continued to evolve and develop due to limited empirical data and the need for better productivity of scaffolding practice in LNG projects (Hou et al. 2017). Consequently, different managerial approaches have been developed and used in the scaffolding supply chain, particularly during the planning stage of the project (Kim et al. 2016), as well as operation of the constructed facility (Kumar et al. 2013). There is an obvious lack of fundamental research on scaffolding procurement. Therefore, analysis of scaffolding procurement is required, particularly to determine the characteristics of its supply chain in $\mathrm{LNG}$ projects.

\section{Methodology}

Due to the required in-depth analysis of subcontracting practices in scaffolding, the case study was adopted in the research methodology (Yin 2013). More importantly, other reasons why a case study was preferred over other field research methods would be due to its ability to enable an investigation of complex issues with scaffolding subcontracting through exploration and address the objectives of this study (Flyvbjerg 2006). Chan et al. (2008) have adopted a similar data gathering method to determine what causes falls from scaffolding to happen during maintenance and repair work. The case study was conducted primarily through obtaining information from and permissions to interview the stakeholders involved in an Australian LNG infrastructure project. Multiple unstructured qualitative interviews were conducted with twelve 
(12) of the practitioners involved in a period throughout 2015 and early 2016.

The number of practitioners interviewed who were involved in the same LNG infrastructure project was also the principle behind the selection of case study organisations. Because they were employed by the organisations being studied, their involvement in this LNG infrastructure project would have ranged from direct to indirect. For example, this meant that those interviewees employed by an organisation being studied, but were not directly involved in this particular project, had also been included together with the research participants sampled. While the conclusions drawn from these case study organisations may not universally apply for every project type, the collective experiences of this extended number of research participants were not be limited to LNG infrastructure projects. Their roles in the scaffolding supply chain were as representatives of the head contractor, supplier and transportation company. These respondents were initially contacted via email correspondence. They had been selected on the basis of their involvement in the same project and were employed in senior management roles at their organisations.

A pilot semi-structured instrument had been used for the first four (4) research participants interviewed to determine its effectiveness. Some minor alterations had been made to refine the interview instrument. The refined instrument had been used for the remaining interviews then after. Other than particulars on their name, organisation, role and profile, the following probing questions were asked using a generic interview protocol - What does your organisation do? Have you come across any issues while working with your client on this project? Have you come across any issues while working with your subcontractors on this project? What could have been done to prevent the issues encountered? What can be done to improve learning to prevent the issues encountered? Would you have any other comments? It was discovered during the preliminary pilot interviews that the scaffolding supplier, as well as the transportation company, generally did not have access to the budgetary information of the LNG infrastructure project they were subcontracted in. Hence, it was not possible to obtain information on the project budget from the supplier and transportation company representatives sampled. This information would have been biased as it is normally limited only to the head contractor involved.

From the many approaches of conducting a case study, the process oriented approach had been used primarily to inquire into instances of scaffolding subcontracting and present meaningful findings on the current situation (Flyvbjerg 2006). These qualitative inquiries had served to make sense of the underlying philosophical influences of scaffolding practices. Therefore, three (3) organisations were selected. Whilst all the organisations selected operate their businesses within Australia, the first two of these would actually be global companies with their origins in Germany and United States respectively. This served as a qualitative ethnographic study that investigated how the scaffolding practices could be differentiated between each of the organisations (Merriam, Tisdell 2015). An ethnographic study is defined by Merriam and Tisdell (2015) as the "focusing on the cultural dimension of a specific case". Benefits, shortcomings, risks and procurement strategies associated with each of the subcontracting arrangements would be discussed in the forthcoming section.

\section{Results and analysis}

\subsection{Scaffolding subcontracting case studies}

Subcontracting arrangements between organisations in the scaffolding supply chain could either include supplying, delivering, labour or a combination of any of these. Their activities will be described based on the issues of current practice in scaffolding previously reviewed. As mentioned previously, different procurement strategies would have some influence upon the contractual roles and responsibilities of the project client, as well as other stakeholders. The project client communicated a set of requirements to the head contractor for them to construct their deliverables. The head contractor had subcontracted a supplier who could satisfy their requirements for scaffolding to be delivered onto the site. The scaffolding supplier would then subcontract out the transportation of their products.

\subsection{Organisation one}

Organisation one is the head contracting company that specialises in carrying out the planning, management, execution and maintenance of various large scale resource facilities. Their tailor made integrated solutions and services are aimed toward general improvements in the efficiency, safety and comfort of life within industrial working environments. The familiarity of the head contractor with issues that emerge from various industrial situations like continuously changing project conditions, requirements for new materials and legislative changes usually mean that they are capable of providing solutions to each of these. The head contracting company itself has over a century of experience with LNG infrastructure project involvement (Kaefer Integrated Services Pty Ltd. 2015).

Table 2 presents a matrix of the organisation two business models centred upon organisational and project management, as well as fabrication and maintenance. It entails the interrelated business functions and capabilities of the head contracting company based upon three (3) groups of employed in house and contracted external people. Their boards of directors are responsible for developing strategies, implementing standards and systems, as well as promoting economic activity in the regions where they operate. The head contracting company's business is divided into their industrial, marine, offshore, fabrication and maintenance operations. Its corporate headquarters 
(HQ) are responsible for the contract administration and obtaining the technology they require, as a representative of organisation one had explained:

\section{"The contract admin is most important. Because it is here that checking and rechecking would correct many human errors" (head contractor representative).}

Table 2. Matrix of organisation one business functions and capabilities

\begin{tabular}{|c|c|c|}
\hline $\begin{array}{c}\text { Business } \\
\text { model }\end{array}$ & $\begin{array}{l}\text { Business } \\
\text { functions }\end{array}$ & $\begin{array}{l}\text { Business } \\
\text { capabilities }\end{array}$ \\
\hline \multirow[t]{2}{*}{$\begin{array}{l}\text { Organisational } \\
\text { and / or } \\
\text { Project } \\
\text { Managing }\end{array}$} & $\begin{array}{l}\text { Board of } \\
\text { Directors }\end{array}$ & $\begin{array}{l}\text { - Strategy developing; } \\
\text { - Standards implementing; } \\
\text { - Systems implementing; } \\
\text { and / or } \\
\text { - Regional activity pro- } \\
\text { moting. }\end{array}$ \\
\hline & $\begin{array}{l}\text { Corporate } \\
\text { Headquarters } \\
\text { (HQ) }\end{array}$ & $\begin{array}{l}\text { - Administration; and / or } \\
\text { - Technology. }\end{array}$ \\
\hline \multicolumn{2}{|c|}{$\begin{array}{l}\text { Fabrication and / or } \\
\text { Maintenance Operations }\end{array}$} & $\begin{array}{l}\text { - Industry; } \\
\text { - Marine; and / or } \\
\text { - Offshore. }\end{array}$ \\
\hline
\end{tabular}

\subsubsection{Subcontracting benefits to organisation one}

There would be some benefits to organisation one associated with them subcontracting external companies. They have established some close contractual partnerships with other stakeholders in the oil and gas industry that enable them to deliver bespoke technological innovation. It specifically enables them to employ expertise in order to carry out some of the fabrication, refurbishment and servicing work. Each of these would include the supply and delivery of scaffolding. In this instance, relying on the combined knowledge and expertise of their subcontractors provide the head contractor with the ability to guarantee the timely delivery of efficient and innovative solutions to their client upon completion of the project that is within their budget (Kaefer Integrated Services Pty Ltd. 2015).

\subsubsection{Subcontracting shortcomings and risks to organi- sation one}

Conversely, there would also be shortcomings and risks to organisation one associated with them subcontracting external companies. The harsh demands of the LNG infrastructure project had often brought challenges to the subcontracted team. The head contractor had to meet the project client demands for a great degree of technical knowledge, competency, management, safety and quality in workmanship. For example, workers on the offshore platform were constantly exposed to large amounts of ambient noise from engine rooms, even in their areas of accommodation. The head contractor had a set of principles to manage such a responsibility, which was included when the supply of scaffolding was subcontracted out- ward onto organisation two. The responsibility of managing noise upon the delivery of scaffolding onsite was in turn forwarded onto organisation three (Kaefer Integrated Services Pty Ltd. 2015).

\subsubsection{Procurement strategy of organisation one}

The head contractor (organisation one) was involved in this LNG infrastructure project from when they were commissioned by their client from the outset prior to the design stage. They had claimed that this LNG infrastructure project is constructed under a turnkey procurement method to help ensure the safety and comfort of working life in the facility (Kaefer Integrated Services Pty Ltd. 2015). Under the procurement method, this mantra for safe and comfortable onsite working conditions would be ensured predominantly through their capability of implementing the acceptable relevant AS / ISO standards for each. Being situated under the metaphoric umbrella of the design and build procurement approach, the turnkey method would presuppose that organisation one is also capable of providing their own scaffold systems in house.

In contrast to the traditional approach, Table 1 shows the main characteristic of design and build procurement would generally be when both the designing and fabricating work is legally contracted onto a single entity (McGraw Hill Construction 2014). This would emphasise the benefits of its relative simplicity in singular accountability, as well as an opportunity to increase efficiency by overlapping both the design and fabrication (Rowlinson, McDermott 1999). Despite these benefits, a shortcoming with this procurement method is that using a contractor to justify a design and / or fabrication methodology could initially be regarded a fire fighting reaction, particularly if used to reduce the amount of unionised labour involved (Webster et al. 1997). Yet, other benefits are that the supply of manufactured scaffolding products would still normally be outsourced onto a subcontracted supplier for purposes of specialisation or economics. Again, despite these benefits, another shortcoming of subcontracting for this purpose would also be a fire fighting reaction (Webster et al. 1997).

All of these characteristics of design and build procurement may well still be true for their manufacture, supply and / or delivery to the site. Despite these capabilities and the peculiarities of a design and build approach, organisation one did not pursue to provide their own scaffold systems. Instead, they appeared to have implemented a fundamental aspect of the divided contract approach to procure scaffolding by subcontracting its supply onto organisation two for their own organisational interests.

\subsection{Organisation two}

The supplier company has been specialising in and offering complete scaffold solutions to fulfil the specific requirements of their customers for almost two decades. In their specialisation, they have been supplying scaffolding to an extensive range of projects across various industries 
and adhere to rigorous quality assurance procedures. The supplier company utilises their expertise and commitment toward safety in providing a range of scaffolding products including ring locks, tubes, clamps and working platforms. They are capable of offering creative scaffolding solutions tailored for the bespoke requirements of their customers, as a representative of organisation two describes (Atlantic Pacific Equipment Inc. 2017):

"For the material ... This is what you want (brief). Then, let them determine what they want to modify to suit their budget. Or change the budget" (scaffolding supplier representative).

The supplier company has been continuing their expansion internationally. Through their subcontracted logistics company (organisation three), they are able to consistently supply complete scaffold solutions to their customers (Atlantic Pacific Equipment Inc. 2017).

Table 3 presents a matrix of the organisation two business model centred upon both the supply and supervision of scaffold equipment. It entails the interrelated business functions and capabilities of the scaffold supplying company based upon six (6) groups of employed in house and contracted external people. The supply of scaffolding equipment can either be rented, sold, leased toward ownership or undergo their buyback program. Their planning and estimating operations has responsibilities in the workface, critical path and reviewing milestones. The designing and engineering functions of the scaffold supplying company encompass the selection of materials and labour estimates to produce shop drawings. The managing and consulting responsibilities of the scaffold supplying company can be at the project level, with superintendents, as well as providers of safety personnel, engineering design and product training. They conduct facilitating and training of scaffolding globally that can include their onsite yard setting up. Their tracking and reporting functions involve database creation.

\subsubsection{Subcontracting benefits to organisation two}

There were some benefits identified by organisation two associated with being the subcontractor for the supply of scaffolding. Their involvement with organisation one had provided them with some additional exposure into the resources market to diversify the capabilities of their business further. In particular, by attracting more work in both the short and long term future on the back of their scaffolding supply to this LNG infrastructure project. The scale of income received from a contractor in the resources sector would typically be significantly greater than from many of its counterparts that operate within other sectors of the Australian economy. There were also some benefits identified by organisation two associated with them subcontracting out the transportation of scaffolding. The most obvious of these would be that the transportation of scaffolding responsibilities was not entirely theirs. They were also able to harness the transportation exper-
Table 3. Matrix of organisation two business functions and capabilities

\begin{tabular}{|c|c|c|}
\hline $\begin{array}{c}\text { Business } \\
\text { model }\end{array}$ & $\begin{array}{l}\text { Business } \\
\text { functions }\end{array}$ & $\begin{array}{c}\text { Business } \\
\text { capabilities }\end{array}$ \\
\hline \multirow[t]{3}{*}{$\begin{array}{l}\text { Scaffold } \\
\text { Equipment } \\
\text { Supplying }\end{array}$} & $\begin{array}{l}\text { Supplying } \\
\text { Arrangements }\end{array}$ & $\begin{array}{l}\text { - Rental supplying; } \\
\text { - Sale supplying; } \\
\text { - Lease to owning; and / or } \\
\text { - Buyback program. }\end{array}$ \\
\hline & $\begin{array}{l}\text { Planning and / } \\
\text { or Estimating }\end{array}$ & $\begin{array}{l}\text { - Workface planning; } \\
\text { - Critical path; and / or } \\
\text { - Milestone reviewing. }\end{array}$ \\
\hline & $\begin{array}{l}\text { Designing } \\
\text { and / or } \\
\text { Engineering }\end{array}$ & $\begin{array}{l}\text { - Design of scaffold mate- } \\
\text { rials; } \\
\text { - Labour estimating; and / } \\
\text { or } \\
\text { - Shop drawings. }\end{array}$ \\
\hline \multirow[t]{3}{*}{$\begin{array}{l}\text { Scaffold } \\
\text { Equipment } \\
\text { Supervising }\end{array}$} & $\begin{array}{l}\text { Managing and } \\
\text { / or Consulting }\end{array}$ & $\begin{array}{l}\text { - Project managing; } \\
\text { - Superintendents; } \\
\text { - Safety personnel; } \\
\text { - Engineering design sup- } \\
\text { porting; and / or } \\
\text { - Product training. }\end{array}$ \\
\hline & $\begin{array}{l}\text { Facilitating } \\
\text { and / or } \\
\text { Training }\end{array}$ & $\begin{array}{l}\text { - Global facilitating; } \\
\text { - Onsite yard setting up; } \\
\text { and / or } \\
\text { - Scaffolding training. }\end{array}$ \\
\hline & $\begin{array}{l}\text { Tracking } \\
\text { and / or } \\
\text { Reporting }\end{array}$ & $\begin{array}{l}\text { - Database creating; and / } \\
\text { or } \\
\text { - Reporting. }\end{array}$ \\
\hline
\end{tabular}

tise of their subcontractor. This enabled them to make significant savings on both the associated time and outlay costs of transportation. This would be consistent with the suggestion of Errasti et al. (2007) that cost savings could indeed be made by outsourcing activities onto suppliers with access to the procedural knowledge required.

\subsubsection{Subcontracting shortcomings and risks to organi- sation two}

Conversely, there were some shortcomings and risks identified by organisation two associated with being the subcontractor for the supply of scaffolding. The responsibility for supplying the adequate quantities of scaffolding products as and when they are required was theirs alone. This was problematic when scaffolding product shortages were encountered. The responsibility for the safety of scaffolding supplied was also theirs. There were also some shortcomings and risks to organisation two associated with them subcontracting out the transportation of scaffolding. The supply of scaffolding products included warranties to cover their replacement for manufacturing defects. These were claimed by the head contractor regularly for defects in stability, load bearing capacities and quality. These claims had significantly added to the transportation costs of the supplier in particular, much of which was not covered as a contingency in their quotation to the head contractor. Because the transportation of their scaffolding products was subcontracted out, the sup- 
plier subsequently had very limited control over quality and delivery times.

\subsubsection{Procurement strategy of organisation two}

Organisation two was initially requested by the head contractor (organisation one) to provide a quotation for the supply of scaffolding in this LNG infrastructure project following its design stage prior to construction without a tender process. This had established that they were subcontracted under a project management procurement method of the divided contract approach. The scaffolding supplier (organisation two) had advocated that they too would engage in subcontracting practice in order to support the capabilities and functions of their business. In this case study, they had subcontracted the logistics company (organisation three) under a divided contract procurement approach, but through the management contracting procurement method. This is because organisation two and their subcontractor would have no other involvement in the LNG infrastructure project than what they had been contracted to undertake. As a representative of the scaffolding supplier had emphasised, they would require a conscious effort to ensure cooperation and effectively improve design constructability (Morledge et al. 2013):

\section{"Contracted staff is to be responsible for their own education of current building practices and environmental efficiencies" (scaffolding supplier representative).}

Table 1 shows the main characteristics of the divided contract procurement approach would indeed comprise the methods of both project manage and management contracting (Rowlinson, McDermott 1999; Walker 2007). A significant shortcoming with the divided contract approach would be that there are actually no clearly established criteria set for selecting any of these methods. This is because of its perceived benefit that they would be tailor made to better suit certain characteristics of an LNG infrastructure project in particular (APCC 2014). Another benefit observed with the divided contract approach was that prices provided by subcontractors for their contributions would be factored into the overall contract sum (Standen 1995).

\subsection{Organisation three}

The logistics company regularly operates over 600 of their vehicles to a dozen cities and towns throughout Australia based on customer demands. The logistics company has seven depots with hardstand and warehouse storage facilities in three of these cities and towns across Western Australia. Their resources logistics operations support the supplier company (organisation two) through goods receiving, storage, container packing, shrink wrapping of equipment and transportation (CTI Logistics Ltd. 2015). The logistics company has also installed satellite tracking Global Positioning System (GPS) technology into all of their vehicles to enhance their service by being able to inform organisations within the supply chain on the locations of freight being delivered at any given time (Navman Australia 2014). This satellite based system gives all of their vehicles the visibility to be monitored at any time from the moment they depart a location. The GPS technology also enables communication with their drivers anytime, particularly when they are located outside the mobile phone coverage (CTI Freightlines 2015). The extent of communication possible with the use of this technology had also been expressed by a representative of organisation three:

\section{"Communication between all the parties in- cludes the consultants, clients and contractors" (transportation company representative).}

Table 4 presents a matrix of the organisation three business model centred upon both the supply and storage of general goods. It entails the interrelated functions and capabilities of the transportation company based upon six (6) groups of employed in house and contracted external people. The largest of these would be their transporting function that is responsible for couriers, parcel delivering, taxi trucking, fleet managing, hauling, container and freight forwarding. The transportation company also has a manufacturing function is responsible for plumbing fittings and un-plasticised polyvinylchloride (PVC) injecting. Their warehousing and logistics function is responsible for distributing, temperature controlled and bulk product storing, picking, packing, as well as stock controlling. Its records managing function is responsible for storing, imaging, scanning and destructing documents. Their pest controlling function is responsible for termite inspecting and treating, quarantining, as well as fumigating. Its securing function is responsible for alarming, closed circuit television (CCTV) installing, monitoring, servicing and accessing control systems.

\subsubsection{Subcontracting benefits to organisation three}

There were some benefits to organisation three associated with being the subcontractor for the transportation of scaffolding. Their involvement with a major customer like organisation one would be likely to ensure that more income would be generated from a greater continuation of work. This would particularly be true in the limited pool of competitors within the local freight transportation market with the same capabilities to transport fragile goods from Perth to the Pilbara and even interstate into the Northern Territory of Australia. The involvement of organisation three with a supply chain to the oil and gas industry has added to the diversification of the transportation services this company would be capable of providing.

\subsubsection{Subcontracting shortcomings and risks to organi- sation three}

Conversely, there were also some shortcomings and risks to organisation three associated with being the subcontractor for the transportation of scaffolding. The scaffold- 
Table 4. Matrix of organisation three business functions and capabilities

\begin{tabular}{|c|c|c|}
\hline $\begin{array}{c}\text { Business } \\
\text { model }\end{array}$ & $\begin{array}{l}\text { Business } \\
\text { functions }\end{array}$ & $\begin{array}{c}\text { Business } \\
\text { capabilities }\end{array}$ \\
\hline \multirow[t]{2}{*}{$\begin{array}{l}\text { General } \\
\text { Goods } \\
\text { Supplying }\end{array}$} & Manufacturing & $\begin{array}{l}\text { - Plumbing fittings; and / or } \\
\text { - Un-plasticised polyvinyl- } \\
\text { chloride (PVC) injecting. }\end{array}$ \\
\hline & Transporting & $\begin{array}{l}\text { - Couriers; } \\
\text { - Parcel delivering; } \\
\text { - Taxi trucking; } \\
\text { - Fleet managing; } \\
\text { - Heavy / line hauling; } \\
\text { - Container transporting; } \\
\text { and / or } \\
\text { - Freight forwarding. }\end{array}$ \\
\hline \multirow[t]{4}{*}{$\begin{array}{l}\text { General } \\
\text { Goods } \\
\text { Storing }\end{array}$} & $\begin{array}{l}\text { Warehousing } \\
\text { and / or } \\
\text { Logistics }\end{array}$ & $\begin{array}{l}\text { - Distributing; } \\
\text { - Temperature controlled } \\
\text { product storing; } \\
\text { - Bulk product storing; } \\
\text { - Picking / packing; and / or } \\
\text { - Stock controlling. }\end{array}$ \\
\hline & $\begin{array}{l}\text { Records } \\
\text { Managing }\end{array}$ & $\begin{array}{l}\text { - Storing; } \\
\text { - Imaging; } \\
\text { - Scanning; and / or } \\
\text { - Document destructing. }\end{array}$ \\
\hline & $\begin{array}{l}\text { Pest } \\
\text { Controlling }\end{array}$ & $\begin{array}{l}\text { - Termite inspecting / treat- } \\
\text { ing; } \\
\text { - Quarantining; and / or } \\
\text { - Fumigating. }\end{array}$ \\
\hline & Securing & $\begin{array}{l}\text { - Alarming; } \\
\text { - Closed circuit television } \\
\text { (CCTV) installing; } \\
\text { - Monitoring; } \\
\text { - Servicing; and / or } \\
\text { - Accessing control systems. }\end{array}$ \\
\hline
\end{tabular}

ing products also needed to be handled carefully due to their fragility upon imposed impacts, weights and heat. Toward this end, all of the straps, ratchets, chains, binders, crates and containers used had to be in good condition, as well as effectively positioned prior to travel. The single way distance the vehicles owned by this company were required to travel was at around 1,400 kilometres. The return journeys were toward the safety limits of their freight transportation capabilities (CTI Freightlines 2015).

The potential for an emergency, like a breakdown, required their vehicles to carry adequate potable water and be tracked by GPS technology from Navman Australia (2014). The drivers were to have rest breaks of at least 30 minutes for every 5 hours of travel time, which was an important measure to avoid fatigue and refuel the vehicle. Information provided by the Australian Government's Bureau of Meteorology was monitored before and during these trips for any warning of adverse weather conditions that could have potentially delayed the transportation of scaffolding products along this route. Adverse weather conditions were identified as a major risk to their estimated travel time of 17 hours plus resting breaks. Beyond the Perth metropolitan area traffic was not identified as a major risk to their estimated travel time, particularly as much of the planned route involved travelling along Northwest Coastal Highway (Commonwealth of Australia 2015; CTI Freightlines 2015).

\subsubsection{Procurement strategy of organisation three}

Organisation three was involved in this LNG infrastructure project during its construction stage as and when their logistics services were required by the scaffolding supplier (organisation two) without a tender process. This had established that they were also subcontracted under a management contracting procurement method of the divided contract approach. Organisation three had been contracted to support the scaffolding rental supplying capability of organisation two. At the time of this case study, they had been contracted for the LNG infrastructure project duration only. Consequently, only the transporting business function of organisation three had been contracted. According to the logistics company (organisation three), there had not been a need to contract out any part of their transporting business function onto another subcontractor.

Table 1 also shows that the characteristics of this particular untraditional procurement method would not always necessarily be devoid of the problematic disadvantages inherent with the traditional approach (Walker 2007; Walker, Rowlinson 2008). Indeed, the management contracting procurement method would essentially be performed only by the people involved with it (Rowlinson, McDermott 1999; Walker, Rowlinson 2008). For instance, the freedom that any incompatibilities of the scaffolding supplier could be either embraced, neglected or outsourced further onto the company with the specialist expertise in logistics and vehicles that are otherwise unavailable to them (Webster et al. 1997). Dependent upon the situation and primary subcontracting objective, this freedom could be either advantageous or disadvantageous to the scaffolding supplier and logistics companies.

\section{Discussion}

The research has discovered that the decision for organisations to subcontract in oil and gas supply chains would invariably involve implementing a divided contract approach. This would be a deviation away from the structured traditional bidding approach. It was under the competitive traditional approach that the head contractor had been contracted by the project client. Their selection may have been based either upon the lowest cost / time, perceived quality, or premise that the organisation had the complete set of capabilities to complete this particular LNG infrastructure project themselves. What is clear from this LNG infrastructure project was that the head contractor had indeed contractually engaged other organisations to help them with procuring its deliverables. In turn, this practice was also evident in each of the subcontracted organisations throughout the scaffolding supply chain presented in this paper. 
The research also has revealed that the question of which procurement method is better for subcontracting should be answered based upon priorities at the project, rather than organisation level. Despite the megaproject magnitudes of the oil and gas industry, the traditional approach is far too cost and human resource intense for its procurement methods to also be implemented by subcontracted organisations. This then remains the more selfdirected procurement methods of subcontractor selection in the divided contract approach. Those that were used for subcontracting in this supply chain were the project manage and management contracting procurement methods. The project management procurement method was found to be effective in saving costs and providing a subcontractor with greater market exposure, but can hinder QA. Conversely, management contracting was found to be particularly useful when the choice of subcontractor is limited, but their risks can affect the entire project and are more difficult for the contractor to control.

\section{Conclusions}

The contribution to the body of knowledge of this research is through the presentation of the LNG infrastructure scaffolding supply chain, as well as the technical review and analysis of subcontracting practices from three case study organisations involved within it. Within this supply chain, the organisations studied generally were the head contracting, scaffolding supplying and transportation companies. The qualitative data was gathered from a review of relevant literature, as well as multiple unstructured interviews with 8 practitioners involved in the oil and gas sector of the Australian construction industry. These qualitative inquiries had served to make sense of the underlying philosophical influences of scaffolding practices.

The business functions and capabilities of three case study organisations that were involved in the same construction project have been presented. The benefits, shortcomings and risks associated with the subcontracting arrangements within the LNG infrastructure scaffolding supply chain were then discussed. For this particular construction project, whilst it was found that all of the business functions of the head contractor were used in some way, the two subcontractors studied each had a more diverse range of services to offer than what they were contracted to perform. Critical to the profitability of this supply chain, it was also found that issues relating to QA, warranties and rework have the potential to mitigate any immediate cost benefits obtained from the practice of subcontracting certain business functions onto other organisations.

\section{Acknowledgements}

The authors would like to express their acknowledgement on all of the support and data provided by Atlantic Pacific Equipment Inc., CTI Logistics Ltd and Kaefer Integrated Services Pty Ltd.

\section{Funding}

This work was supported by the ARC [grant number LP140100873].

\section{Disclosure statement}

The authors of this article declare to have no competing financial, professional or personal interests from other parties.

\section{References}

APCC. 2014. Building and construction procurement guidePrinciples and options. Australian Procurement and Construction Council, Sydney, Australia.

Artto, K.; Eloranta, K.; Kujala, J. 2008. Subcontractors' business relationships as risk sources in project networks, International Journal of Managing Projects in Business 1(1): 88-105. https://doi.org/10.1108/17538370810846432

Atlantic Pacific Equipment Inc. 2017. AT-PAC - Complete scaffolding solutions [online], [cited 22 July 2017]. Available from Internet: https://www.at-pac.com/

Bhagwati, J.; Panagariya, A.; Srinivasan, T. N. 2004. The muddles over outsourcing, The Journal of Economic Perspectives 18(4): 93-114. https://doi.org/10.1257/0895330042632753

Chan, A. P. C.; Wong, F. K. W.; Chan, D. W. M.; Yam, M. C. H.; Kwok, A. W. K.; Lam, E. W. M.; Cheung, E. 2008. Work at height fatalities in the repair, maintenance, alteration and addition works, Journal of Construction Engineering and Management 134(7): 527-535.

https://doi.org/10.1061/(ASCE)0733-9364(2008)134:7(527)

Choudhry, R. M. 2014. Behavior based safety on construction sites - A case study, Accident Analysis and Prevention 70: 14-23. https://doi.org/10.1016/j.aap.2014.03.007

Chung, K. F.; Yu, W. K. 2002. Mechanical properties of structural bamboo for scaffoldings, Engineering Structures 24(4): 429-442. https://doi.org/10.1016/S0141-0296(01)00110-9

CIOB. 2010. A report exploring procurement in the construction industry. Berkshire, UK: The Chartered Institute of Building.

Commonwealth of Australia. 2015. Australia's official weather forecasts and weather radar. Bureau of Meteorology [online], [cited 24 September 2015]. Available from Internet: http://www.bom.gov.au/

CTI Freightlines. 2015. Journey management plan. Perth, Australia: CTI Logistics Limited.

CTI Logistics Ltd. 2015. Welcome to CTI freight lines [online], [cited 6 April 2015]. Available from Internet: http://www.ctifreightlines.com.au/

Enshassi, A.; Arain, F.; Tayeh, B. 2012. Major causes of problems between subcontractors in the Gaza Strip, Journal of Financial Management of Property and Construction 17(1): 92-112. https://doi.org/10.1108/13664381211211064

Errasti, A.; Beach, R.; Oyarbide, A.; Santos, J. 2007. A Process for developing partnerships with subcontractors in the construction industry - An empirical study, International Journal of Project Management 25: 250-256. https://doi.org/10.1016/j.ijproman.2006.10.002

Flyvbjerg, B. 2006. Five misunderstandings about case study research, Qualitative Inquiry 12(2): 219-245. https://doi.org/10.1177/1077800405284363

Girma, S.; Görg, H. 2004. Outsourcing, foreign ownership and productivity - Evidence from UK establishment level data, Review of International Economics 12(5): 817-832. https://doi.org/10.1111/j.1467-9396.2004.00483.x

Goh, Y. M.; Binte-Sa'adon, N. F. 2015. Cognitive factors influencing safety behaviour at height - A multimethod 
exploratory study, Journal of Construction Engineering and Management 141(6): 04015003.

https://doi.org/10.1061/(ASCE)CO.1943-7862.0000972

Government of Western Australia. 2012. Long service leave Determining whether your people are subcontractors or employees for contribution purposes [online], [cited 6 April 2015]. Available from Internet:

http://www.myleave.wa.gov.au//wp-content/uploads/2012/07/MyLeave-Employee-or-Sub-Contractor.pdf

Grossman, G. M.; Helpman, E. 2005. Outsourcing in a global economy, The Review of Economic Studies 72(1): 135159. https://doi.org/10.1111/0034-6527.00327

Hartmann, A.; Caerteling, J. 2010. Subcontractor procurement in construction - The interplay of price and trust, Supply Chain Management an International Journal 15(5): 354362. https://doi.org/10.1108/13598541011068288

Hou, L.; Zhao, C.; Wu, C.; Moon, S.; Wang, X. 2017. Discrete firefly algorithm for scaffolding construction scheduling, Journal of Computing in Civil Engineering: 04016064. https://doi.org/10.1061/(ASCE)CP.1943-5487.0000639

Humphrey, J.; Schmitz, H. 2002. How does insertion in global value chains affect upgrading in industrial clusters?, Regional Studies 36(9): 1017-1027. https://doi.org/10.1080/0034340022000022198

Jha, K. N.; Iyer, K. C. 2006. Critical determinants of project coordination, International Journal of Project Management 24: 314-322. https://doi.org/10.1016/j.ijproman.2005.11.005

Jones, M.; Kraatz, J. 1997. National module ABC 038 - Drawing office practice 2 learner's guide. Brisbane, Australia: The State of Queensland - Open Learning Institute of TAFE.

Kaefer Integrated Services Pty Ltd. 2015. There for you all over the world [online], [cited 6 April 2015]. Available from Internet: http://www.kaefer.com

Kim, K.; Cho, Y.; Zhang, S. 2016. Integrating work sequences and temporary structures into safety planning - Automated scaffolding related safety hazard identification and prevention in BIM, Automation in Construction 70: 128-142. https://doi.org/10.1016/j.autcon.2016.06.012

Kumar, C.; AbouRizk, S. M.; Mohamed, Y.; Taghaddos, H.; Hermann, U. 2013. Estimation and planning tool for industrial construction scaffolding, in Proceedings of the $30^{\text {th }}$ International Association for Automation and Robotics in Construction (IAARC), 2013, Bratislava, Slovakia, 634-642.

Leahy, D.; Montagna, C. 2009. Outsourcing vs FDI in oligopoly equilibrium, Spatial Economic Analysis 4(2): 149-166. https://doi.org/10.1080/17421770902833964

Liu, J.; Meng, F.; Fellows, R. 2015. An exploratory study of understanding project risk management from the perspective of national culture, International Journal of Project Management 33: 564-575. https://doi.org/10.1016/j.ijproman.2014.08.004

Manu, E.; Ankrah, N.; Chinyio, E.; Proverbs, D. 2015. Trust influencing factors in main contractor and subcontractor relationships during projects, International Journal of Project Management 33: 1495-1508. https://doi.org/10.1016/j.ijproman.2015.06.006

Merriam, S. B.; Tisdell, E. J. 2015. Qualitative research -A guide to design and implementation. John Wiley and Sons.

Moon, S.; Forlani, J.; Wang, X.; Tam, V. 2016. Productivity study of the scaffolding operations in liquefied natural gas plant construction - Ichthys project in Darwin, Northern territory, Australia, Journal of Professional Issues in Engineering Education and Practice 142(4): 04016008. https:// doi.org/10.1061/(ASCE)EI.1943-5541.0000287

McGraw Hill Construction. 2014. Project delivery systems How they impact efficiency and profitability in the buildings sector. Smart market report. Bedford, USA.

Morledge, R.; Smith, A.; Kashiwagi, D. T. 2006. Building procurement. Oxford, UK: Blackwell.

Navman Australia. 2014. Best GPS navigation systems / units [online], [cited 24 September 2015]. Available from Internet: http://www.navman.com.au/

Pan, N. H. 2009. A hybrid optimization mechanism for constructing a dynamic simulation system - An operational behavior analysis of a moving scaffolding system, Automation in Construction 18(7): 881-893. https://doi.org/10.1016/j.autcon.2009.03.012

Póvoas, A. A. 2012. The utilization of movable scaffolding systems in large spans, Structural Engineering International 22(3): 395-400.

https://doi.org/10.2749/101686612X13363869853374

Pieńko, M.; Błazik-Borowa, E. 2013. Numerical analysis of load bearing capacity of modular scaffolding nodes, Engineering Structures 48: 1-9. https://doi.org/10.1016/j.engstruct.2012.08.028

Rowlinson, S.; McDermott, P. 1999. Procurement systems - A guide to best practice in construction. London, UK: E \& FN Spon.

Rubio-Romero, J. C.; Rubio, M. C.; García-Hernández, C. 2012. Analysis of construction equipment safety in temporary work at height, Journal of Construction Engineering and Management 139(1): 9-14. https://doi.org/10.1061/(ASCE)CO.1943-7862.0000567

Spencer, B. J. 2005. International outsourcing and incomplete contracts, Canadian Journal of Economics / Revue Canadienne D'Economique 38(4): 1107-1135. https://doi.org/10.1111/j.0008-4085.2005.00317.x

Standen, D. 1995. Construction industry specifications. Melbourne, Australia: Royal Australian Institute of Architects (RAIA) Practice Services.

Titus, S.; Bröchner, J. 2005. Managing information flow in construction supply chains, Construction Innovation 5(2): 71-82. https://doi.org/10.1108/14714170510815186

Walker, A. 2007. Project management in construction. $5^{\text {th }}$ ed. London, UK: Blackwell.

Walker, D. H. T.; Rowlinson, S. 2008. Procurement systems A cross industry project management perspective. New York, USA: Taylor and Francis.

Webster, M.; Alder, C.; Muhlemann, A. P. 1997. Subcontracting within the supply chain for electronics assembly manufacture, International Journal of Operations and Production Management 17(9): 827-841. https://doi.org/10.1108/01443579710171055

Yin, R. K. 2013. Case study research - Design and methods. Sage Publications.

You-Wei, Z. X. Y. Z.; Jin, S. U. N. 2005. Insertion in global value chains and industrial upgrading - An empirical research on Suzhou and Wenzhou (J), International Trade Journal 4: 13.

Yu, W. K.; Chung, K. F.; Chan, S. L. 2005. Axial buckling of bamboo columns in bamboo scaffolds, Engineering Structures 27(1): 61-73. https://doi.org/10.1016/j.engstruct.2004.08.011 
Robert LOPEZ. Dr. Is a Research Fellow and Digital Learning Coordinator for the Department of Construction Management in School of Built Environment (SoBE) at Curtin University, Bentley. He received his Building Design and Drafting Diploma from Central Institute of Technology, Leederville. Dr Lopez completed both his BAppSc (Honours) degree and PhD (Chancellor Commendation) in Construction Management at Curtin University, Bentley. His areas of expertise involve Building Design and Drafting, Quantity Surveying, Design and Construction Management, Building Technology, Project Procurement and Dispute Resolution, as well as BIM.

Heap-Yih CHONG. Dr. Is a Senior Lecturer in the Department of Construction Management within School of Built Environment (SoBE) at Curtin University, Bentley. He is a Chartered Builder (UK) and former Council Member (Malaysia) of the CIOB. Dr Chong is also a Malaysian Institute of Arbitrators Registered Arbitrator, as well as Commentator and Contributor for Civil Engineering Standard Form of Contract in Malaysia. His areas of expertise involve Business and Project Management, Sustainability, BIM, Infrastructure Construction, Arbitration and Contracts, as well as Quantity Surveying.

Sungkon MOON. Dr. Is a Lecturer and Program Director in Risk Management and (deputy) Construction Management within the Department of Civil \& Construction Engineering at Swinburne University of Technology, Hawthorn. He received his BSc and MSc degrees from Hanyang University, Seoul. Dr Moon completed his PhD at University of New South Wales (UNSW), Sydney. His areas of expertise involve Dynamic Control via Construction Technologies, The Fourth Industrial Revolution and Automated Construction, Logistics and Supply Chain Management, Project Performance Management, as well as Computer-aided Engineering.

Xiangyu WANG. Professor, has a dual affiliation with Curtin University and Kyung Hee University. He is a Woodside Chair at the Australasian Joint Research Centre for Building Information Modelling in the Department of Construction Management within School of Built Environment (SoBE) at Curtin University, Bentley. Professor Wang is also an International Scholar at the Department of Housing and Interior Design in the College of Human Ecology at Kyung Hee University, Seoul. His areas of expertise involve Construction Information (IT) and Visualisation Technologies, BIM, Lean, as well as Project Management. 